\title{
Developing an Assessment Framework for Affordable and Sustainable Housing
}

Stephen Pullen, Michael Arman, George Zillante, Jian Zuo, Nicholas Chileshe and Lou Wilson (Institute for Sustainable Systems and Technologies University of South Australia)

\begin{abstract}
Sustainable housing has been subject to research, practice and policy making for some considerable time. More recently attention has been drawn to the separate problem of declining affordability in housing. This paper describes research aimed at developing an assessment framework for both affordability and sustainability as part of the effort to incorporate both of these features into new housing projects. The research has a particular focus on developments aimed at urban densification. Background literature on both affordability and sustainability is reviewed as well as emerging schemes aimed at dealing with both aspects of housing developments. Performance indicators are identified and these are incorporated in an interim assessment framework which is tested using a group of industry experts. The research has highlighted areas where further development is required to attain quantitative assessments of affordable and sustainable housing developments.
\end{abstract}

Keywords: Assessment, Indicators, Affordability, Sustainability, Construction

\section{Introduction}

Interest in environmentally sustainable housing has risen significantly in recent years, as one response to the global goal of attaining sustainable development. Such a trend in policy, regulation and practice is founded on an assumption that reducing the environmental impact of housing will result in long-term benefits. Sustainable housing discourse and practice is focused on the physical application of well-grounded principles in the design of dwellings and the methods and materials used in construction (Randolph et al., 2008; Low et al., 2005). More recently sustainability in housing developments has become associated with the trend towards urban densification (SA Govt, 2009).

Although regulatory changes are ensuring gradual improvements in the environmental performance of all housing, environmentally sustainable housing has not been widely developed in Australia. This is particularly the case at the lower end of the housing market perhaps owing to deeper structural factors or inaccurate perceptions of sustainable housing (Sibley et al., 2003; Buys et al., 2005).

Paradoxically the need for environmentally sustainable housing is greatest in the affordable housing sector. This is because improvements to the environmental performance of housing, such as improved energy efficiency, provide particular ongoing economic benefits to lowerincome households. These households spend a greater proportion of their income on utilities and are least likely to be in a position to afford energy efficiency improvements without assistance (Winston and Eastaway, 2007).

At the same time, the well developed policy and literature in Australia regarding affordable housing (such as Yates, 2007; Gurran et al., 2008; Disney, 2007; Department for Families and Communities, n.d.; Australian Government, 2008) has emphasised the social and economic sustainability implications of a growing challenge to housing affordability without addressing environmental objectives. Indeed, the Australian experience of increasing 
affordability is that such housing tends to be poorly located on cheap land and built to minimise construction costs, resulting in lower environmental performance and questionable social acceptability (Arman et al., 2009a).

It is widely thought that environmental features in dwellings are inconsistent with affordability, argued, for example, by Yates et al. (2008 p.63) who suggest that "measures to ensure environmental sustainability are likely to increase the capital cost of providing housing and, consequently, the housing costs".

This paper presents research carried out within the Ecocents Living project concerned with housing that is both affordable and sustainable. The project was particularly aimed at infill developments consistent with the aim of increasing urban housing densities (SA Govt, 2009) rather than master planned greenfield developments. The paper follows on from earlier work in the project (Arman et al., 2009a; Arman et al., 2009b; Zillante et al., 2009; Zillante et al., forthcoming) which has provided a theoretical foundation to the research, considered the conceptual tensions between affordability and sustainability, and grappled with core definitional issues. This paper builds on this conceptual work and develops an assessment framework which seeks to link indicators of affordability with those of economic, social and environmental sustainability. The assessment framework will assist the development of a model of affordable and sustainable housing particularly for infill developments.

This paper is structured as follows:

- the background section summarises relevant literature and existing assessment frameworks;

- following this a series of possible indicators of affordable and sustainable housing are identified, resulting in the development of an interim assessment framework;

- the results section summarises the outcomes of the testing of the assessment framework which took place at an industry discussion forum;

- the outcomes from of the research are summarised in the conclusion.

\section{Research Methodology}

The objective of this paper is to describe the development and testing of a single framework for the assessment of the affordability and sustainability in residential developments consistent with recent trends towards housing densification in urban areas.

As identified in the shaded section of Figure 1, the research methodology has two components. Existing literature and assessment frameworks were initially analysed to provide a necessary context for an assessment framework for affordable and sustainable housing. This process highlighted and addressed some of the challenges associated with sustainability assessment frameworks and the need to apply systems thinking. The review also identified characteristics and possible indicators of affordable and sustainable housing, to influence an interim assessment framework.

The second component of the methodology was an industry discussion forum, where a panel of 12 experts was assembled to test the interim assessment framework and thus provide necessary refinement and industry input. The forum was held in October 2009 and participants, who were provided with the interim assessment framework prior to the forum, were asked to reflect on five questions, in a semi-structured discussion. 


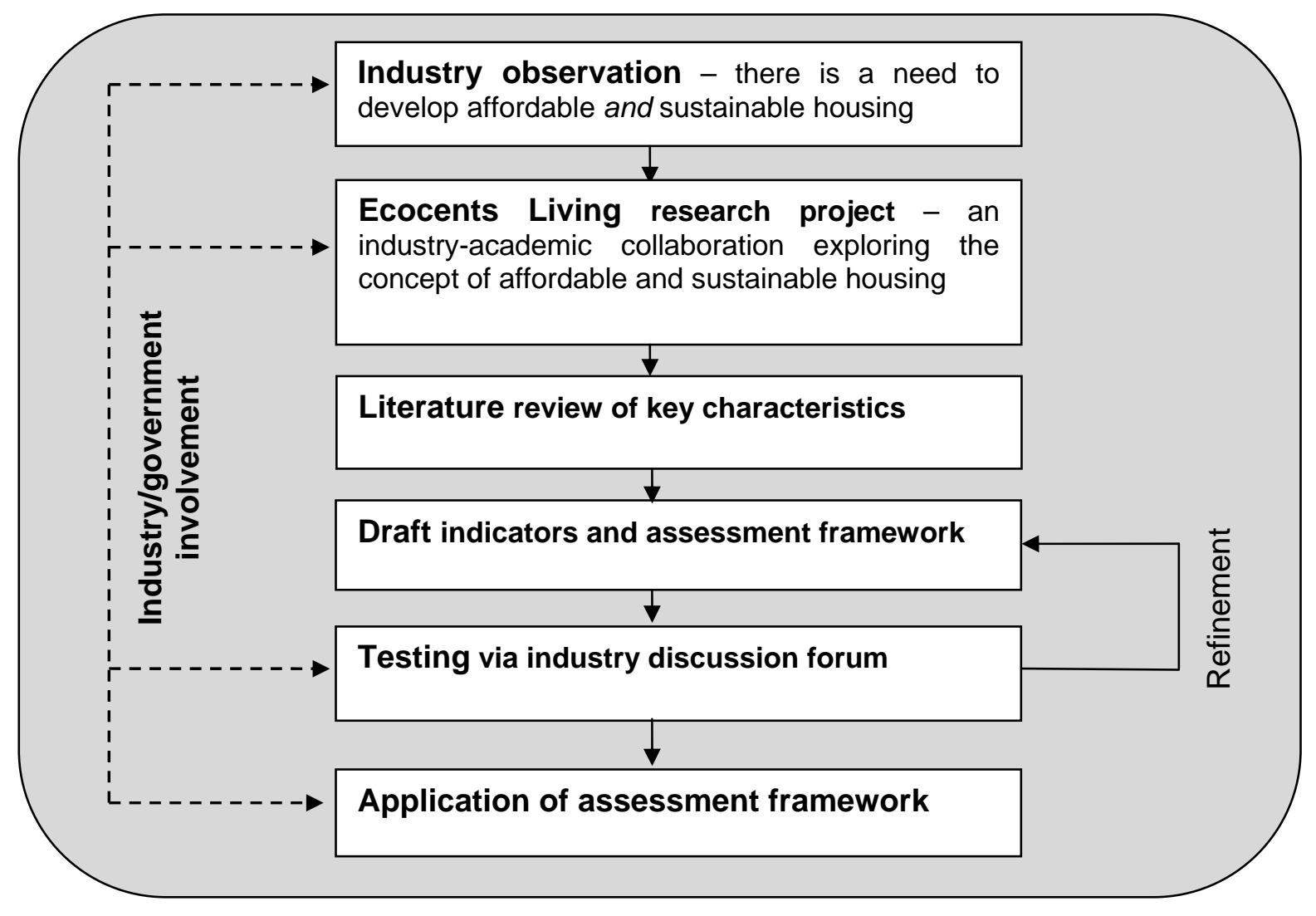

Figure 1 Context and scheme of research for the Ecocents Living project.

\section{Background}

The simultaneous analysis of affordability and sustainability is under-developed in Australia. While it has been generally agreed that environmentally sustainable housing should be affordable (see, for example, Randolph et al., 2008), and that affordable housing should not come at the expense of recurrent costs, thermal comfort and quality (Winston and Eastaway 2007), research into the design and construction of affordable and sustainable building systems is still at an early stage.

\section{Housing Affordability}

Improving housing affordability is now a mainstream public policy concern, reflected in the numerous active policies and initiatives (see, for example, Australian Government 2008; COAG 2009; Department for Families and Communities n.d.; City of Salisbury 2009 for examples of innovations at national, state and local government levels).

The literature regarding housing affordability in Australia is well developed. Numerous studies, such as Berry 2003, Yates et al. 2007, Gurran et al. 2008, Disney 2007, Beer et al., 2007 and Gurran et al., 2008, have quantified the extent of affordability challenges and unpacked the reasons behind these as well as identifying policy implications and possible solutions.

\section{Sustainable Housing Frameworks}

Commonly sustainable housing is presented as being synonymous with ecologically sustainable development in housing, which in some cases is reduced to manageable frameworks around environmental performance, or just energy efficiency. An example of this is the Reducing the Environmental Impact of Housing report released by the Environmental Change Institute of the University of Oxford (Palmer et al., 2006). 
This comprehensive study was prepared for the UK Royal Commission for Environmental Pollution which provides evidence to support policy and debate (RCEP 2009). The study starts from a broad theoretical base in identifying the following priority themes for the Commission:

- Sustainable urban transport;

- Sustainable urban management (including Local Agenda 21);

- Sustainable urban construction (encompassing resource and energy efficiency, demolition waste, design issues);

- Sustainable urban design (encompassing land use regeneration, brown field sites, urban sprawl, land use densities.

(Palmer et al., 2006)

However, while acknowledging that the environmental impact of housing transcends all these broad urban sustainability themes, with housing associated with far-reaching and longterm impacts, the report quickly reduces its focus to the key area of energy, in addition to some very limited discussion on land use, waste production and water. However, there are now a growing number of frameworks and tools that seek to assess the environmental performance of housing, and the indicators for these are increasingly wide-ranging and well developed. The most recent contribution has been produced by the Urban Development Institute of Australia (UDIA) in their EnviroDevelopment ranking system (UDIA, 2009) which has a strong emphasis on environmental sustainability. EnviroDevelopment provides a marketing branding for an evidence-based assessment system. Assessment against the framework is voluntary but provides consumers with accurate knowledge to compare different developments. The standards have been developed through collaboration with industry, government and other experts (UDIA, 2009).

\section{Integrated Assessment Frameworks}

In terms of integrated assessment frameworks, the most comprehensive research into affordability and sustainability was undertaken by Blair et al., (2004). This project involved a triple bottom line analysis of the sustainability of a 'traditional' regulatory subdivision compared with a master planned community. The research identified the economic, social and environmental components of sustainable housing and in the process, developed a set of 37 equally weighted indicators which were categorised as follows:

- Housing affordability $(n=12)$

- Sense of community, neighbourhood safety, and satisfaction $(n=8)$

- Transportation $(n=3)$

- Environment - biodiversity $(\mathrm{n}=2)$

- Environment - energy ( $n=6)$

- Environment - resources consciousness $(n=4)$

- Environment - wastewater/stormwater control $(n=2)$

(Blair et al., 2004)

Like many Triple Bottom Line (TBL) analyses there were challenges with the differing levels of sophistication amongst the indicators, with the 14 environmental indicators being relatively well developed, while others, such as those regarding affordability and sense of community, were less well developed. This was then reflected in the discussion and analysis, which contained comparatively more discussion around the environmental indicators. The study highlighted that it is very difficult to develop a truly rigorous TBL assessment that gives sufficient consideration to economic, social and environmental criteria as there are often strong but difficult to quantify inter-relationships between these components (Blair et al., 2004).

More recently, VicUrban, the Victorian government's urban development agency, has developed a 'sustainable community rating system' to provide a "common language" about 
sustainability in the development of master planned, urban renewal and provincial (nonmetropolitan) communities (VicUrban, 2010).

The sustainable community rating system is built around five objectives, each of which has several priorities. The sustainable community rating system relies on the widely accepted Brundtland definition of sustainable development, and while there are no formal TBL criteria, the rating system has strong economic, social/cultural and environmental themes. The five objectives are:

- Commercial success;

- Housing affordability;

- Urban design excellence;

- Community well-being;

- Environment.

(VicUrban, 2010)

In the sustainable community rating system, housing affordability is presented as a key objective of a 'sustainable community'.

\section{Sustainability Assessment Frameworks and Systems Thinking}

Conceptualising and operationalising the idea of sustainability results in many tensions (Baker, 2006, Sneddon et al., 2006, Davidson, 2005). As Kasemir et al. (2003 in Rotmans 2006 p.37) note, sustainability is a contested concept because it is inherently complex, normative, subjective and ambiguous. Although the inter-relationships between, for example, the economic, social and environmental spheres of development are well documented, there are many pragmatic challenges in holding these tensions in balance and progressing toward a sustainable future (Arman, 2009a).

In moving towards a sustainable future, we must grapple with what Rotmans (2006 p.37) calls the "sustainability paradox". The paradox is that our current sustainability problems cannot be solved with current methods and tools that were developed or worked in the past. However, at the same time, we cannot be inactive and wait for the next generation, and their problem solving tools, methods and ideas.

The future of sustainability assessment may lie in the adoption of a systems thinking approach (Davidson and Venning, 2009; Daniell et al., 2005). Systems thinking suggests that the component parts of any system can be best understood in the context of relationships with other components and other systems, rather than in isolation. Thus, in terms of sustainability, a systems approach may allow a shift from the 'silo' approach of individual economic, social and environmental components of sustainability to one which recognises the inter-relationships between the components. To this end, Davidson and Venning (2009) p.10) suggest that "a sustainable outcome cannot be assured if each key component of the system is not incorporated within the decision making framework".

In perhaps an early application of a more integrated approach to sustainability assessment involving systems thinking, Daniell et al. (2005) applied the Assessment of Urban Systems Through Integrated Modelling and Exploration (AUSTIME) methodological framework to a particular housing development in Adelaide. Using this model, they were able to combine carbon dioxide, water, waste, ecosystem health, economic and social subsystems into a multi-agent model, and in the process, simulate a variety of changes in occupant behaviour, infrastructure and location. This project represents a progression in debates around sustainability assessment, in that it highlights the relative importance and effects of various subsystems to the overall sustainability. 


\section{Indicators of Affordable and Sustainable Housing}

This section of the paper identifies key indicators of affordable and sustainable housing which form the basis of an interim assessment framework.

Before highlighting key indicators of affordability and sustainability, it is necessary to understand at a broad level what constitutes 'affordable and sustainable housing'. Sparks (2007) defines green affordable housing as "housing that is better designed and built, more durable, not significantly more expensive, cheaper to operate, healthier, more environmentally sound, and less risky" (Sparks 2007 in Arman et al., 2009b, p.13). Global Green USA (2007, p.1) also talks about green affordable housing and adds that such housing "forges a strong link between social justice and environmental sustainability, and connects the wellbeing of people with the wellbeing of the environment, thus building on the core social and economic values of affordable housing".

Arman et al. (2009b) reviewed a variety of definitions of affordability, affordable housing, sustainability and sustainable housing and arrived at a conceptual definition of affordable and sustainable housing:

Housing that meets the needs and demands of the present generation without compromising the ability of future generations to meet their housing needs and demands. Affordable and sustainable housing has strong and inter-related economic, social and environmental components (Arman et al., 2009b, p.13).

In that study, the authors argued that while it serves as a useful aspirational aim, such a definition lacks clarity and like many definitions, challenges exist when such aspirational aims are applied to different contexts and are potentially manipulated to serve predetermined objectives (Arman et al., 2009b, p.14). They suggested that more specific criteria may be required to ensure that affordability and sustainability in housing are actually realised. To this end, the study arrived at ten 'characteristics' of affordable and sustainable housing. These broad characteristics sought to reflect literature on affordability (characteristics 1-4) economic sustainability (characteristics 5-6), social sustainability (characteristics 6-7) and environmental sustainability (characteristics 8-10). Thus, an affordable and sustainable dwelling is:

1. A product where the rent or mortgage repayments do not exceed $30 \%$ of household incomes for the bottom $40 \%$ of income groups.

2. A product that is appropriately located.

3. A product that is of a suitable size and quality for its occupants.

4. A product that does not increase the incidence of housing stress over the lifecycle of the house.

5. A product where individual and government financial obligations can be met on an ongoing basis without policy change.

6. A product that is socially acceptable.

7. A product that does not increase social exclusion or polarisation.

8. A product that is located on a site that minimises biodiversity losses.

9. A product that is located on a site that maximises low-energy transportation options.

10. A product that encompasses the following environmental features

- Energy efficiency;

- Passive solar design;

- Sun shading;

- Water conservation

- Appropriate waste management during construction, occupation and deconstruction

(Source: Arman et al., 2009b, p.15)

Pullen, S et al. (2010) 'Developing an assessment framework for affordable and sustainable housing', Australasian Journal of Construction Economics and Building, 10 (1/2) 48-64 
Although these characteristics flag some key issues, they are far from an assessment framework. In developing an interim affordability and sustainability assessment framework, the following notes seek to build on these characteristics by outlining eleven possible performance indicators of affordable and sustainable housing, as well as possible performance measures for these. Additionally, in response to the need for a systems approach, at a conceptual level, a brief comment is made on each of the indicators in terms of possible synergies or tensions that the indicator may present in terms of affordability and sustainability. The following indicators are grounded in the above characteristics but have been modified and expanded upon to reflect established best practice in more recent housing developments, particularly with respect to urban infill housing projects which are the focus of the Ecocents Living Project.

\section{Energy Efficiency}

Energy Efficiency encompasses active and passive measures to reduce energy consumption and greenhouse gas emissions of dwellings and represents one of the biggest areas where housing can make a contribution to sustainable development (Kibert, 2008; Larsen et al., 2008). Possible measures for energy efficiency include star ratings, passive design and the adoption of specific technologies such as photovoltaic cells and solar water heating.

Energy efficiency measures are often thought to be inconsistent with affordability, with, for example, concern expressed by the construction industry regarding up-front costs associated with star-rating changes to the Building Code (BCA 2009). However, improved energy efficiency can markedly improve the ongoing energy costs of households (Winston and Eastaway, 2008).

\section{Water Efficiency}

Water Efficiency encompasses water conservation, storage and re-use measures as well as water sensitive urban design techniques (Apostolidis and Hutton, 2006; Liu et al., 2009; BEDP, 2008). Water conservation, storage and re-use can be applied at the scale of the whole development and at the scale of individual lots. Possible measures of water efficiency include rainwater storage and re-use, water efficient appliances, application of water sensitive urban design (WSUD) principles and grey water re-use.

As with energy efficiency, this indicator can be associated with increased up-front costs.

\section{Construction Materials}

Construction Materials relates to the selection of materials such as the use of low embodied energy new materials and the re-use and recycling of old materials. Reducing embodied energy can contribute to lowering the overall life cycle energy consumption of homes (Pullen et al., 2006). In addition, careful analysis and selection of the materials used and the way they are combined can yield significant improvements in the comfort, cost effectiveness and energy efficiency of a home. Possible performance measures for this indicator include the use of recycled or renewable materials, the embodied energy and the use of low volatile organic compound (VOC) building materials.

There are a variety of conflicting requirements associated with the selection of materials used in construction. Specifically, the use of recycled or renewable materials may impact favourably on affordability but some of these materials might not be socially acceptable. Certain materials and construction components might also impinge on the ability to appropriately modify and adapt a dwelling to suit the changing needs of the occupant. 


\section{Construction Methods}

Construction Methods relates to methods and techniques, including new innovations, that will contribute to improved affordability and environmental sustainability. There are many methods in use in the Australian context and each has advantages and disadvantages depending on factors such as climate, availability of materials and skilled labour, budget and social acceptability and appearance. Possible performance indicators include the use of alternative or conventional construction methods, prefabrication and internal thermal massing.

Innovation in construction methods must be considered in the context of the contribution to affordability and sustainability, not just advancement in technology. For example, while prefabricated houses may have the potential to maximise energy efficiency as well as minimising waste and controlling cost, they may not be desirable and thus not marketable (Craig et al., 2000).

\section{Affordability - Price Mechanism}

Affordable housing is housing that is reasonably adequate in standard and location for a lower or middle-income household and does not cost so much that such a household is unlikely to be able to meet other basic living costs on a sustainable basis (National Summit on Housing Affordability, 2006). Stone (2005) notes that affordability is not a characteristic of housing per se, but rather, it is a relationship between housing and people that depends on answering three questions:

- Affordable to whom?

- On what standard of affordability?

- For how long?

(Stone, 2005, p.153)

While there are many economic and social determinants of affordability (including costs of running a home and associated travel over the life of the household), the most widely used measure in Australia (use by, for example, Australian Government, 2008; Beer et al., 2007; Berry et al., 2004; Disney, 2007; Gurran et al., 2008; Yates et al., 2007; Yates et al., 2008) is the '30/40 split' which suggests that housing costs should not exceed $30 \%$ of household income for the bottom $40 \%$ of income groups. Knowing average incomes, it is then possible to calculate an affordable house cost in terms of purchase price and rent (such as Department for Families and Communities, n.d.) and such figures may determine eligibility for certain affordable housing schemes (as in City of Salisbury, 2009).

There are many tensions associated with price mechanisms, not the least of which is that they may not reflect true market housing costs. Indeed, in some instances, the only way to find housing that meets the strict cost is in locations that may be neither socially acceptable, nor environmentally sustainable in terms of travel required by households. Difficulties can be experienced in maintaining affordable housing costs when delivering certain environmental features or innovative technologies (Yates et al., 2008). However, durable houses where ongoing maintenance costs are kept to a minimum dictate good design with robust materials which often means higher construction costs.

\section{Desirability}

Desirability of a dwelling refers to how it meets and exceeds the consumers' expectations. The market is an excellent indicator of desirability (i.e. do people want to buy this product, as distinct from do they need this product) and is a measure of desirability that is not dependent on some form of subjective assessment Betts and Ely (2005). It can be measured by the average price paid for a property in a development through auctions or sales, or by average rents. It might also be measured by the average appreciation (or depreciation) in the value of homes in the development over time. In some social housing projects, where the homes 
sales are restricted to low income earners, the appreciation of homes or the average time a property remains on the market for similar properties in the local area might serve the same function.

\section{Density and Urban Form}

Although there are no agreed standard definitions, housing density generally refers to the number of housing units in a given area (Forsyth, 2003). Density and the associated urban form is important considering the well-documented links between the imposition of urban growth boundaries, increasing land costs and housing unaffordability (see, for example, Yates, 2007, Australian Government, 2008). In a general sense, increased urban densities have been linked to improved sustainability (Rickwood et al., 2008). Specifically, as densities increase the short term costs of providing key infrastructure drop, particularly for infill developments where existing infrastructure can be utilised. Additionally, per capita energy consumption can reduce, especially when residents make a transition from private vehicles to public transport and levels of walking and cycling increase (Towers 2002; Hall 2001). However, Perkins et al. (2009) have suggested that high density development does not guarantee lower overall per capita greenhouse gas emissions.

\section{Dwelling Size}

Large dwelling sizes can unnecessarily reduce affordability and environmental sustainability. Conversely minimum floor areas are required for health and well-being. Floor area requirements can depend on the number of occupants but Australia currently has no such regulatory standards. Minimum dwelling size regulations ensure that the size of rooms and storage spaces in residential developments provide for the well-being of residents (Design for Homes, 2006).

Determining what is an appropriate dwelling size in terms of affordability and sustainability is not a straightforward exercise. While housing costs and energy consumption are likely to decline with reduced dwelling sizes, such dwellings may not be social acceptability or desirable to the market. Moreover space in a dwelling should be sufficient to provide for residents' changing needs. In this sense, minimum dwelling sizes play a role in the provision for adaptability.

\section{Adaptability}

Adaptability is used to describe a house that has been constructed to allow low-cost and low-energy modifications to suit the changing needs of the occupants. An adaptable house is one which is able to respond effectively to changing household needs without requiring costly and energy intensive alterations. Low cost adaptation is important in ensuring buildings are durable, embodied energy is minimised and resource consumption is reduced (Mercer et al., 2007). There are also socio-cultural benefits attached to building easily adaptable housing (Bullen, 2007), not the least of which is allowing older residents to easily and cost-effectively remain in the familiar environment of their home. Adaptability is often reflected by the application of 'Universal Design Principles' (ANUHD, 2009; Connell et al., 1997).

While it may seem obvious to build all homes to be adaptable, this too is associated with many trade-offs. Although adaptable homes may seem cost-effective in the long-term, it inevitably involves some additional up-front costs, which may be at odds with the initial purchase costs of a dwelling.

\section{Social Acceptability}

Social Acceptability is defined as the acceptability of a development by the surrounding community. Although it can be difficult to pin-point what factors of a development contribute to its social acceptability, the overall level of acceptability can be gauged through a variety of 
mechanisms (Syme et al., 2005). For example, formal objections to a development submitted to a Development Assessment Panel are frequently submitted by members of the community as an expression of perceptions of the development. Responses to local or state government community consultations on significant developments are an expression of social acceptability. Social acceptability can also be determined by the acceptance or rejection of a development application by local or state government. Thus, social acceptability can exist on a variety of scales and as such it is an indicator that may be indirectly quantified.

\section{Interim Assessment Framework}

Figure 2 summarises the aforementioned indicators of affordable and sustainable housing and presents them as interim assessment framework.

As discussed in the literature review, in terms of sustainability assessment frameworks,

What we can do, however, is using current knowledge, tools and methods in the best possible manner, while developing a new paradigm that better reflects the complexity of sustainability (Rotmans, 2006, p.37).

In light of this, while acknowledging the complexity associated with the simultaneous assessment of affordability and sustainability, an assessment framework using the above indicators has tentatively been developed which will use current knowledge and methods in the best possible manner. It is acknowledged that difficulties will always be encountered when balancing and/or prioritising the economic, social and environmental considerations, particularly when affordability is an issue that is more than housing costs.

When considering various indicators of affordability and sustainability the only way appropriate trade-offs between and weightings of the various indicators will effectively occur is through contested debate between various stakeholders (Arman et al., 2009a). To this end the draft assessment framework shown in Figure 2 was presented to a diverse group of construction industry, public policy and community representatives to be 'road tested'. This framework links the many different components of affordability and sustainability and a summary score then provides an indication of which development is more affordable and sustainable.

\section{Results}

\section{Background to the Industry Discussion Forum}

A discussion forum was held to discuss the interim assessment framework and facilitate discourse about affordable and sustainable housing. The industry and community sectors that were represented included:

- Construction firms

- Architectural firms

- Urban and social planning firms

- Local government

- Minister's Strategic Housing Advisory Committee

- Land Management Corporation, government land development agency

- Housing SA, government housing agency

- 'Consumer' of affordable and sustainable housing

In preparation for the discussion group, participants were asked to reflect on the following questions:

- How well do the definitions (stated under the assessment framework) reflect your understanding of the terms?

- Are there any issues or indicators which have been overlooked in the assessment framework? 


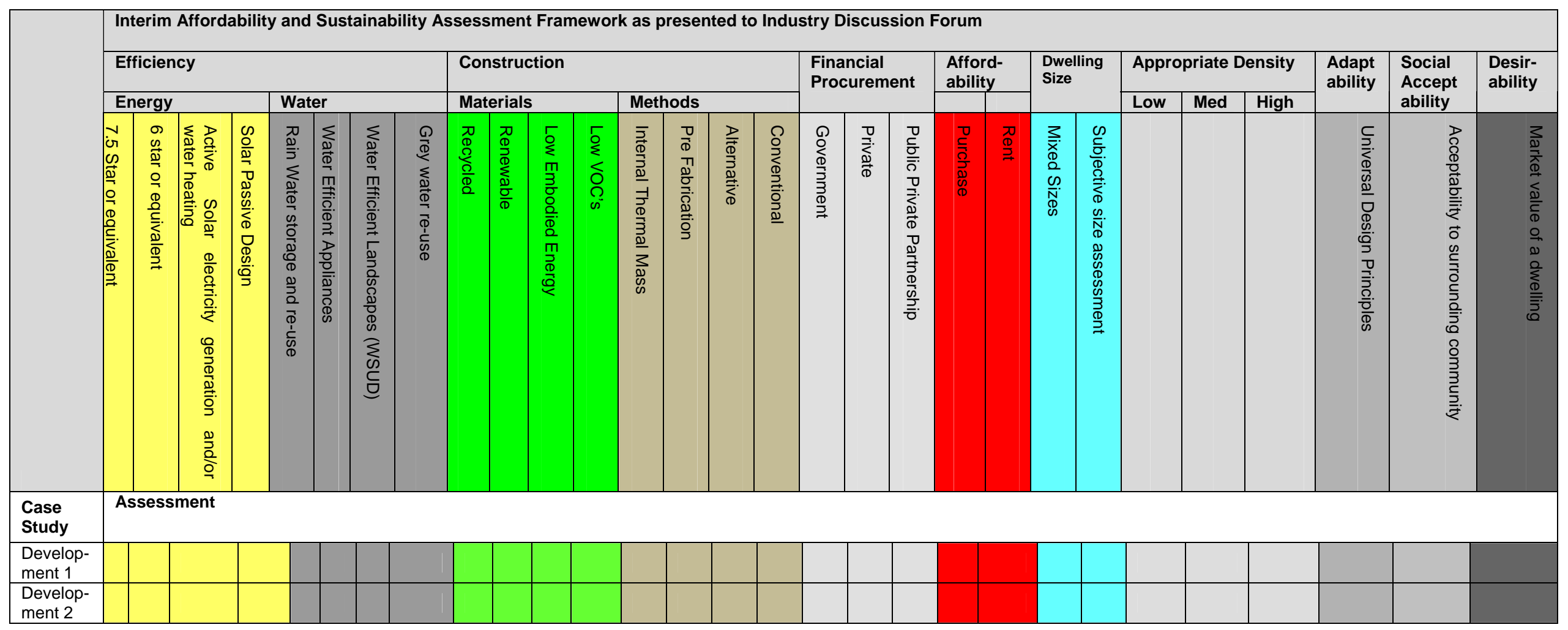

Figure 2 Interim Affordability and Sustainability Assessment Framework as presented to Industry Discussion Forum 
- How important is it to be able to measure "soft" indicators, such as social acceptability? How easily can this be done?

- In what ways could an affordability and sustainability assessment tool for housing work for you in the realisation of successful housing outcomes?

- What are appropriate housing solutions that are affordable and will be environmentally, socially and economically sustainable?

\section{Key Outcomes of the Discussion Group}

Overall, the participants were enthusiastic about the assessment framework as it integrated components of environmental, economic and socially sustainability housing as well as key aspects of affordability.

Specifically there was discussion on the need to decouple the indicators for energy efficiency and energy generation. In terms of materials it was recommended that a stronger emphasis was needed on durability and robustness, as well as on issues of ongoing maintenance and occupants' health.

There was an interesting debate around innovations in construction materials and methods, in that some participants felt that structures in the industry, such as the Building Code of Australia, were limiting the pursuit of non-conventional materials and methods. Such regulation and structures potentially inhibit options that are affordable and environmentally sustainable.

In terms of building adaptability, participants noted that Universal Design Principles (Connell et al., 1997; ANUHD, 2008) address adaptability in an holistic manner and that these agreed standards should be the benchmark in assessing the adaptability of housing. It was suggested that the Building Code of Australia potentially has a role to play in ensuring Universal Design Principles are incorporated in new dwellings.

The following aspects were suggested for possible inclusion in the assessment framework:

- Safety: this could include both physical features to facilitate passive surveillance, such as Crime Prevention through Environmental Design (see, for example, Davey et al., 2005) techniques, as well as residents' perception of safety in their neighbourhood.

- Quality of life: this indicator could assess the overall well-being and quality of life of occupants, reflecting issues such as time lost in travel, opportunities to develop social capital and the role of the home in wealth creation.

- Quality of place: this indicator could address design issues, both at a dwelling and neighbourhood scale. A strong theme at the discussion forum was that successful affordable and sustainable housing outcomes may only be achievable through a high standard of design, and as such, strong design codes are needed.

- Health: the discussion group noted that the physical form of dwellings and neighbourhoods has considerable scope to facilitate physically and socially healthy communities. It was, for example, noted that walkability within a neighbourhood to basic services such as local schools and shops not only has health benefits but also contributes to the development of social capital.

\section{Housing Affordability}

Discussion group participants spent considerable time discussing housing affordability, the issues contributing to the problem, potential solutions and effective measures to adequately quantify housing affordability. 
Participants were generally in agreement that simple income to housing cost ratios used to derive certain purchase and rental prices for housing (as used as performance measures for affordability in the interim framework) poorly reflect the many issues that contribute to decreasing housing affordability. Similarly, there was agreement that it is impossible to consider housing affordability without an in-built transportation factor, considering the substantial impact transportation can have on households' living costs over a 25 year period. The example given was that while it may be affordable to purchase a home on the urban fringe for a relatively low cost, over a 25-year period its occupants may spend the same value as the initial purchase price in excessive transportation costs. It was thus suggested that indicators of affordability must somehow consider the life-cycle costs of living in the dwelling, in relation to transportation costs, not just affordability at the point of sale.

Discussion group participants reinforced the notion that any housing outcomes should seek to provide affordable housing across many different market segments, encompassing both subsidised housing as well as those struggling with home purchase and in the private rental market. This idea is well developed in the literature (see for example Disney, 2007, Berry, 2003) and has been a guiding principle for the entire project.

In summary, the diverse and collective expertise of participants at the discussion group provided the necessary testing for the assessment framework. The results of testing the framework is summarised in Table 1 and these will be incorporated as the framework is refined.

\begin{tabular}{|l|l|}
\hline Indicator & $\begin{array}{l}\text { Possible modification/ further research } \\
\text { required }\end{array}$ \\
\hline Energy efficiency & $\begin{array}{l}\text { Decouple performance measures for energy } \\
\text { efficiency from those regarding energy generation }\end{array}$ \\
\hline Construction materials & $\begin{array}{l}\text { Performance measures are needed regarding } \\
\text { robustness/durability and impact on occupants' } \\
\text { health. }\end{array}$ \\
\hline Construction methods & $\begin{array}{l}\text { The relationship between building regulation and } \\
\text { adoption of innovative and non-conventional } \\
\text { methods. Need to consider broader governance } \\
\text { issues }\end{array}$ \\
\hline Affordability & $\begin{array}{l}\text { Consider broader performance measures that } \\
\text { better reflect locational issues, transportation and } \\
\text { land cost. }\end{array}$ \\
\hline New aspects & $\begin{array}{l}\text { Safety } \\
\text { Quality of life } \\
\text { Quality of place } \\
\text { Health }\end{array}$ \\
\hline
\end{tabular}

Table 1 Results of testing of affordable and sustainable housing framework

Generally speaking both the background research into the assessment framework and the discussion forum highlighted the fact that those indicators dealing with environmental sustainability are reasonably well defined (i.e. energy, water, materials and methods). Furthermore, there are tentative levels of performance available for each sub-indicator. This is not the case with the indicators dealing with economic and especially social sustainability (i.e. affordability, dwelling size, density, adaptability, social acceptability and desirability. These indicators require further definition and the methods for measuring performance are in need of considerable research to render the indicators useful when assessing affordable and sustainable housing. Furthermore, the derivation of indicators has highlighted the issue of interdependence and the subjectivity of assessment frameworks in general. 


\section{Conclusions}

The work presented in this paper has sought to develop and test a framework for the assessment of affordability and sustainability in residential developments with particular emphasis on urban infill projects. By considering other research in this area, characteristics of affordability and sustainability have been determined which have enabled performance indicators to be identified. The relevance of these indicators has been tested by reference to experts in the industry. It has been found that those indicators dealing with environmental sustainability are reasonably well defined whereas those reflecting social sustainability need further development. Furthermore there are inherent synergies and tensions between the indicators which require exploration. At this stage the assessment framework can be applied in a qualitative manner to new or existing housing developments in keeping with the sustainability paradox. A quantitative application will depend on the evaluation of more rigorous metrics and the development of mechanisms that consider the inter-relationships between indicators. The work has identified the direction of future research which needs to adopt a more integrated systems-based approach in striving for the goal of housing that is both affordable and sustainable.

\section{Acknowledgements}

The authors gratefully acknowledge the support that the Ecocents Living research project has received from the Department for Families and Communities in the Government of South Australia and Hindmarsh.

\section{References}

ANUHD (2008) Homes for Living, Australian Network for Universal Housing Design, http://www.anuhd.org/content/about-anuhd viewed 8 Jan 2010

Apostolidis, N. and Hutton, N. (2006) Integrated water management in brownfield sites more opportunities than you think, Desalination, 188 (1-3),169-175

Arman, M., Zuo, J., Wilson, L., Zillante, G., Pullen, S. (2009a) 'Challenges of responding to sustainability with implications for affordable housing', Ecological Economics, 68, 3034-041

Arman, M., Wilson, L., Zuo, J., Zillante, G. and Pullen, S. (2009b) 'Conceptualising affordable and sustainable housing: Towards a working model to guide planning and construction', Proceedings of 34th Australasian Universities Building Educators Conference, Barossa Valley, South Australia

Australian Government (2008) Making Housing Affordable Again, Department of Families, Housing, Community Services and Indigenous Affairs, http://www.facsia.gov.au/Internet/ facsinternet.nsf/News/housing_affordable.htm. viewed 4 Dec. 08

Baker, S. (2006) Sustainable Development. Routledge, New York

BCA (2009) Building Code of Australia. Vol 2. Energy Efficiency, Australian Building Codes Board

BEDP (2008) Environmental Design Guide, Australian Council of Built Environment Design Professionals Ltd., http://www.enviornmentdesignguide.net.au viewed 8 Jan 2010

Beer, A., Kearins, B. and Pieters, H. (2007) 'Housing Affordability and Planning in Australia: The Challenge of Policy Under Neo-liberalism', Housing Studies, 22 (1),11-24

Berry, M. (2003) 'Why is it important to boost the supply of affordable housing in Australia and how can we do it?' Urban Policy and Research, 21 (4), 413-435

Berry, M., Whitehead, C., Williams, P. and Yates, J. (2004) Financing Affordable Housing: a Critical Comparative Review of the United Kingdom and Australia. AHURI Final Report No $72 \mathrm{Nov}$

Pullen, S et al. (2010) 'Developing an assessment framework for affordable and sustainable housing', Australasian Journal of Construction Economics and Building, 10 (1/2) 48-64 
Betts, R.M. and Ely, S.J. (2005) Basic Real Estate Appraisal, $6^{\text {th }}$ ed, Thompson South Western, Ohio

Blair, J., Prasad, D., Judd, B., Zehner, R., Soebarto, V. and Hyde, R. (2004) Affordability and Sustainability Outcomes: A Triple-Bottom-Line Assessment of Traditional and Master Planned Communities, Volume 1, Final Report, AHURI, UNSW-UWS Research Centre

Bullen, P.A. (2007) Adaptive reuse and sustainability of commercial buildings, Facilities, 25 20-31

Buys, L., Barnett, K., Miller, E. and Bailey, C. (2005) Smart housing and social sustainability: learning from the residents of Queensland's research house. Australian Journal of Emerging Technologies and Society, 3 (1), 43-57

City of Salisbury (2009) Brahma Green: Driving Affordable Housing in the City of Salisbury, Project Report, http://cweb.salisbury.sa.gov.au/manifest/servlet/binaries?img=8678\&stypen= html viewed 12 Dec 2009

COAG (2009) National Affordable Housing Agreement, Schedule F, Intergovernmental Agreement on Federal Financial Relations, Council of Australian Governments, Department of Prime Minister and Cabinet, Canberra, , http://www.coag.gov.au/intergov_agreements/ federal_financial_relations/docs/IGA_FFR_ScheduleF_National_Affordable_Housing_Agree ment.pdf viewed 5 Mar 2009

Connell, B., Jones, M., Mace, R., Mueller, J., Mullick, A., Ostroff, E., Sanford, J., Steinfeld, E., Story, M. and Vanderheiden, G. (1997) Principles of Universal Design. NC State University. College of Design. http://www.design.ncsu.edu/cud/pubs_p/docs/poster.pdf viewed 8 Jan 2010

Craig, T. P., Laing, R., and Edge, M. (2000) 'The Social Acceptability of Prefabrication and Standardisation in New Housing', Proceedings of papers presented at the 16th Conference of the International Association for People-Environment Studies, 4-6 Jul Paris

Daniell, K., Sommerville, H., Foley, B., Maier, H., Malovka, D. and Kingsborough, A. (2005) Integrated urban system modelling: methodology and case study using multi-agent systems in Zerger, A. and Argent, R. (eds) MODSIM 2005: International Congress on Modelling and Simulation, Modelling and Simulation Society of Australia and New Zealand, 2026-032

Davey, C., Wootton, A., Cooper, R., and Press, M. (2005) 'Design against crime: extending the reach of crime prevention through environmental design', Security Journal, 18, 39-51

Davidson, K. (2005) 'Will the concept of sustainable development provide any solutions of the 21 Century', Social Change in 21st Century, Queensland University of Technology, Oct 2005

Davidson, K. and Venning, J. (2009) 'Applying integrated decision making frameworks for sustainability: An urban context', Australian New Zealand Society of Ecological Economics, Darwin 27th October

Davidson, K. and Wilson, L. (2009) 'An Integrated Model for the Assessment of Urban Social Sustainability' in Procceedings of the State of Australian Cities Conference, Perth, Nov 2009

Department for Families and Communities (n.d). What is Affordable Housing? Adelaide, http://www.dfc.sa.gov.au/pub/tabid/171/itemid/312/What-is-affordable-housing.aspx viewed 1 Dec. 2008

Design for Homes (2006) Swing a Cat. URL: Design for Homes, HATC Ltd and Touch Creative Design Ltd, http://www.swingacat.info/how_much_space.php viewed 29 Jan 2009

Disney, J. (2007) 'Affordable Housing in Australia: Some Key Problems and Priorities for Action', Paper presented at the National Forum on Affordable Housing, 19 Apr 2007, AHURI, Melbourne

Pullen, S et al. (2010) 'Developing an assessment framework for affordable and sustainable housing', Australasian Journal of Construction Economics and Building, 10 (1/2) 48-64 
Forsyth, A. (2003) Measuring Density: Working Definitions for Residential Density and Building Intensity, Design Centre for American Urban Landscapes, Design Brief Number 8, Jul 2003, University of Minnesota, available online http://www.housinginitiative.org/pdfs/from _MDC_Website/db9.pdf

Global Green, USA (2007) Blueprint for Greening Affordable Housing. Island Press, Washington, USA

Gurran, N., Milligan, V. and Baker, D. (2008) New Directions in Planning for Affordable Housing: Australian and International Evidence and Implications, AHURI Final Report No. 120, Sydney Research Centre

Hall, P. (2001) 'Sustainable cities or town cramming?' In Planning for a sustainable future, A Layard, S Davoudi and S Batty (eds), Routledge, London p107

Kibert, C. (2008) Sustainable Construction. John Wiley \& Sons, Oxford

Liu, S., Butler, D., Memon, F.A., Makropoulos, C., Avery, L. and Jefferson, B. (2009) 'Impacts of residence time during storage on potential of water saving for grey water recycling system', Water Research, $\mathbf{4 3}$

Low, N., Gleeson, B., Green, R., Radovic, D. (2005) The Green City: Sustainable Homes, Sustainable Suburbs. UNSW Press, Sydney, Australia

Mercer, T., Tuan, N.B. and Radford, A. (2007) 'What Is Affordable Green Housing? Analysis of a Competition', Journal of Green Building, 2 (1), 130-142

National Summit on Housing Affordability (2006) Achieving a National Affordable Housing Agreement: Background Paper 2: Key Terminology and Indicators, National Summit on Housing Affordability, http://www.housingsummit.org.au/media/BP2c.pdf viewed 1 Dec 2008

Palmer, J., Boardman, B., Bottrill, C., Darby, S., Hinnells, M., Killip, G., Layberry, R. and Lovell, H. (2006) Reducing the Environmental Impact of Housing: Consultancy study in support of the Royal Commission on Environmental Pollution's 26th Report on the Urban Environment, Environmental Change Institute, University of Oxford

Perkins, A., Hamnett, S., Pullen, S., Zito, R. and Trebilcock, D. (2009) 'Transport, Housing and Urban Form: The Life Cycle Energy Consumption and Emissions of City Centre Apartments Compared with Suburban Dwellings', Urban Policy and Research, 27 (4) 377396

Pullen, S., Holloway, D., Randolph, B. and Troy, P. (2006) 'Energy Profiles of Selected Residential Developments in Sydney with Special Reference to Embodied Energy', Proceedings of the Australian \& New Zealand Architectural Science Association (ANZAScA) $40^{\text {th }}$ Annual Conference. 22-25 Nov

Randolph, B., Kam, M. and Graham, P. (2008) Who Can Afford Sustainable Housing in Nelson, A (Ed.) Steering Sustainability in an Urbanising World, Aldershot, United Kingdom

RCEP (2009) Royal Commission on Environmental Pollution: About Us, Royal Commission on Environmental Pollution, http://www.rcep.org.uk/about/index.htm viewed 10 Dec 2009

Rickwood, P., Glazebrook, G. and Searle, G. (2008) 'Urban structure and energy-a review', Urban Policy and Research, 26 (1), 57-81

Rotmans, J. (2006) 'Tools for Integrated Sustainability Assessment: A two-track approach', The Integrated Assessment Journal: Bridging Science and Policy, 6 (4) 35-57

SA Govt (2009) Planning the Adelaide We All Want. Progressing the 30 Year Plan for Greater Adelaide. Department of Planning and Local Government. Government of South Australia. Draft for consultation. Jul

Pullen, S et al. (2010) 'Developing an assessment framework for affordable and sustainable housing', Australasian Journal of Construction Economics and Building, 10 (1/2) 48-64 
Sibley, J., Hes, D. and Martin, F. (2003) 'A triple helix approach: an inter-disciplinary approach to research into sustainability in outer-suburban housing estates', in Proceedings of Methodologies in Housing Research Conference, Stockholm, Sep 2003

Sneddon, C., Howarth, R. and Norgaard, R., (2006). 'Sustainable development in a postBrundtland world', Ecological Economics, 57, 253-268

Stone, M. (2005) 'What is Housing Affordability? The case for the residual income approach" Housing Policy Debate, 17 (1) 151-184

Syme, C., McGregor, V. and Mead, D. (2005) Social Implications of Housing Intensification in the Auckland Region: Analysis and Review of Media Reports, Surveys and Literature. http://www.arc.govt.nz/albany/fms/main/Documents/Auckland/Aucklands\%20growth/Social\% 20 Implications\%20of\%20Housing\%20Intensification\%20Feb\%202005.pdf. viewed 29 Jan 2010

Towers, G. (2002) 'The Implications of Housing Density' in Marana, I and Tsenkova, S. (eds) Challenges and Opportunities in Housing: New Concepts, Policies and Initiatives, CIB WC 69 Housing Sociology, Dec 2002, CIB

UDIA (2009) EnviroDevelopment: How Does it Work, Urban Development Institute of Australia, http://www.envirodevelopment.com.au/01cms/details.asp?ID=17 viewed 9 Dec 2009

VicUrban (2010) Sustainable Community Rating. Governemnt of Victoria. http://www. sustainablecommunityrating.com/cs/Satellite?pagename=SCR viewed 8 Jan 2010

Winston, N. and Eastaway, M.P. (2008) 'Sustainable Housing in the Urban Context: International Sustainable Development Indicator Sets and Housing', Social Indicators Research, 87 (2), 211-221

Yates, J. (2007) 'Australia's Housing Affordability Crisis', The Australian Economic Review, 41 (2), 200-214

Yates, J., Milligan, V., Berry, M., Burke, T., Gabriel, M., Phibbs, P., Pinnegar, S. and Randolph, B. (2007) Housing Affordability: A 21st Century Problem. National Research Venture 3: Housing Affordability for Lower Income Australians, Final Report, AHURI Sydney Research Centre

Yates, J., Kendig, H., Phillips, B., Milligan, V. and Tanton, R. (2008) Sustaining fair shares: the Australian housing system and intergenerational sustainability, Final Report, AHURI Sydney Research Centre

Zillante, G., Arman, M., Davidson, K., Wilson, L., Pullen, S. and Zuo, J. (2009) 'The sustainable and affordable housing debate in Australia', The CRIOCM 2009 International Symposium on "Advancement of Construction Management and Real Estate", 29th -31st Oct 2009, Nanjing, China

Zillante, G., Pullen, S., Wilson, L., Davidson, K., Chileshe, N., Zuo, J. and Arman, M. (forthcoming) 'Integrating affordable housing and sustainable housing: bridging two merit goods in Australia', In Wallis, I., Bilan, L., Smith, M. and Kazi, A.S. (Ed.) Sustainable Construction: Industrialised, Integrated, Intelligent, I3CON handbook 